\title{
A trend study on the impact of social media on advertisement
}

\author{
Seyedeh Sepideh Alavi ${ }^{\mathbf{a}^{*}}$, Iman Mehdinezhad ${ }^{\mathrm{a}}$, Bita Kahshidinia ${ }^{\mathrm{a}}$
}

\begin{tabular}{l}
$\frac{{ }^{a} \text { Department of Progress Engineerin }}{\text { C H R O N I C L E }}$ \\
\hline Article history: \\
Received: October 29, 2018 \\
Received in revised format: Janu- \\
ary 21, 2019 \\
Accepted: February 8, 2019 \\
Available online: \\
February 8, 2019 \\
\hline Keywords: \\
Social network \\
Word of Mouth \\
Advertisement \\
Social media \\
Data analysis \\
\end{tabular}
\section{A B S T R A C T}

\begin{abstract}
This paper presents a comprehensive scientometric study for the impact of social networks on advertisement. The study uses the Scopus database as a search engine to accomplish the survey. To better understand the evolution and identity of this category, the study covers 1216 most cited data over the period 1983-2019. Qualitative and quantitative data analysis techniques are applied to determine author distribution, country, individual and institutional-level productivity rankings. In terms of keywords, the study indicates that social media was jointly studied with gender and behavior and researchers from the United States maintained the highest rate of contribution. The survey also indicates that there were strong collaboration between the researchers from China and United States. Moreover, there were also remarkable collaborations between the researchers in United States from one side and other countries.
\end{abstract}

\section{Introduction}

Social media is one of the primary methods for connecting people with each other and it helps people share their beliefs, ideas and even emotions (Belmonte-Jimenez, 1988; Stieglitz \& Dang-Xuan, 2013). Social media advertising, or social media targeting, are advertisements served to users through social media platforms. This is a competitive advertisement plan (Bimpikis et al., 2016). It may also be used for selling products and services directly (Ramo \& Prochaska, 2012; Ramo et al., 2014) although there are many challenges for online shopping (Guha et al., 2010). Social networks utilize users' information to serve highly relevant advertisements based on interactions within some specific platforms (Zubcsek \& Sarvary, 2011). When a product or service is advertised through internet, it is necessary to detect target people by an appropriate tools (Aggarwal et al., 2014). Sun and Li (2014), for instance, used similaritybased community detection in social network of microblog. In many instances, when target market is aligned with the user demographics of a social platform, social advertising can provide huge increase in conversions and sales with lower cost of acquisition (Zhang et al., 2011, 2012a, b, 2015, 2016a,b). In

* Corresponding author.

E-mail address: spd.alavi@gmail.com (S.S. Alavi) 
terms of therapeutic goals, Facebook provides a forum for reporting personal experiences, asking questions, and receiving direct feedback for people from different issues such as the people who live with diabetes. However, promotional activities and personal data collection are also common, with no accountability for authenticity (Green et al., 2011; Månsson, 2011; Manderson et al., 2012). Word-ofmouth (WOM) advertisement can be encouraged through different publicity activities set up by companies, or by having opportunities to encourage consumer-to-consumer and consumer-to-marketer communications. Moreover as marketers are getting more interested in harnessing the power of WOM, for ebusiness and other net related activities, the effects of the different communications types on macro level marketing is becoming critical (Hansen \& Lee, 2013; Mortazavi, 2014; Remschmidt et al., 2014; Gunasekaran et al., 2013). When a product is advertised on social media, it is important to be so effective that other people re-post the advertisement. Araujo et al. (2015) performed an investigation to find out what motivates consumers to re-tweet brand content by investigating the effect of information, emotion, and traceability on pass-along behavior.

This survey presents a survey on the effect of social media on advertisement. The study covers all peer reviewed articles publisher over the period 1983-2009 which are indexed in Scopus database. The study attempts to shed light on the most common keywords, the highly cited articles and other relevant information commonly used in the literature to survey on the effect of Social media on advertisement.

\section{The most common keywords}

Table 1 demonstrates some of the mostly cited references associated with advertising in social media. As we can observe from the results of Table 1, social networking, marketing and social media are three well recognized keywords used in the literature.

Table 1

The most popular keywords used in studies associated with advertising in social media

\section{Contributions of countries}

Our survey demonstrates that countries from different continents have maintained the most contribution in the field of advertising and social media and it is not focused on a specific geographic area. Table 2 shows details of our survey. 
Table 2

The summary of the contributions of different countries

\begin{tabular}{|c|c|c|c|c|c|}
\hline Country & Total Citations & $\begin{array}{c}\text { Average Article } \\
\text { Citations }\end{array}$ & Country & Total Citations & $\begin{array}{c}\text { Average Article } \mathrm{Ci}- \\
\text { tations }\end{array}$ \\
\hline USA & 3917 & 16.884 & POLAND & 14 & 4.667 \\
\hline ISRAEL & 982 & 327.333 & EGYPT & 13 & 4.333 \\
\hline UNITED KINGDOM & 656 & 20.5 & KUWAIT & 13 & 6.5 \\
\hline AUSTRALIA & 595 & 18.03 & SLOVAKIA & 10 & 2 \\
\hline CHINA & 476 & 5.667 & BAHRAIN & 9 & 9 \\
\hline TAIWAN & 342 & 10.688 & MALAYSIA & 8 & 1.6 \\
\hline GERMANY & 310 & 11.071 & CZECH REPUBLIC & 7 & 2.333 \\
\hline KOREA & 249 & 8.893 & PAKISTAN & 7 & 3.5 \\
\hline BELGIUM & 232 & 17.846 & ROMANIA & 5 & 1 \\
\hline SPAIN & 228 & 3.931 & THAILAND & 5 & 1 \\
\hline INDIA & 213 & 7.1 & IRELAND & 4 & 4 \\
\hline CANADA & 182 & 12.133 & ARGENTINA & 2 & 1 \\
\hline BRAZIL & 128 & 7.529 & JAPAN & 2 & 0.4 \\
\hline AUSTRIA & 126 & 31.5 & SOUTH AFRICA & 2 & 2 \\
\hline NETHERLANDS & 112 & 10.182 & TRINIDAD AND TO- & 2 & 0.667 \\
\hline ITALY & 102 & 7.846 & COLOMBIA & 1 & 0.5 \\
\hline HONG KONG & 99 & 6.6 & ESTONIA & 1 & 1 \\
\hline SINGAPORE & 85 & 8.5 & HUNGARY & 1 & 1 \\
\hline PORTUGAL & 69 & 17.25 & JORDAN & 1 & 1 \\
\hline MEXICO & 54 & 6.75 & MOROCCO & 1 & 1 \\
\hline FRANCE & 51 & 2.684 & NORWAY & 1 & 1 \\
\hline NEW ZEALAND & 39 & 7.8 & QATAR & 1 & 1 \\
\hline CROATIA & 32 & 6.4 & SLOVENIA & 1 & 1 \\
\hline GREECE & 30 & 7.5 & TURKEY & 1 & 0.2 \\
\hline SWEDEN & 26 & 13 & BULGARIA & 0 & 0 \\
\hline SWITZERLAND & 25 & 3.571 & CUBA & 0 & 0 \\
\hline UKRAINE & 22 & 5.5 & GHANA & 0 & 0 \\
\hline FINLAND & 20 & 4 & SAUDI ARABIA & 0 & 0 \\
\hline IRAN & 14 & 2 & SERBIA & 0 & 0 \\
\hline LUXEMBOURG & 14 & 7 & SRI LANKA & 0 & 0 \\
\hline
\end{tabular}

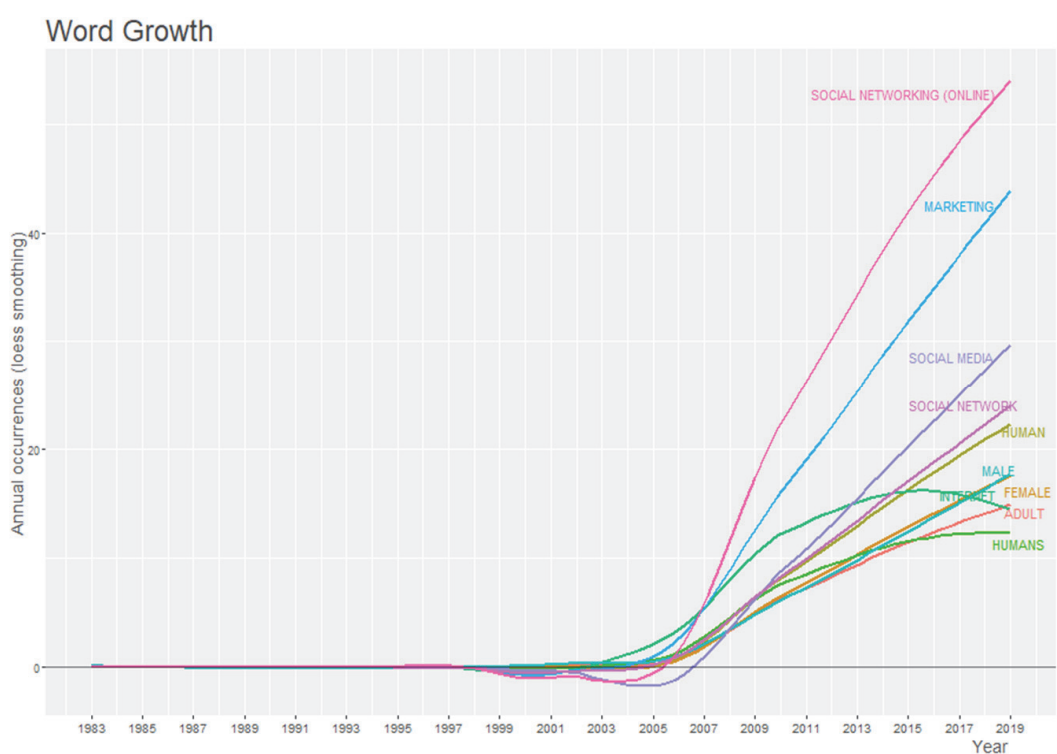

Fig. 1. The summary of the most popular keywords used in papers about advertising in social media

According to Table 2, researchers from USA have published 3917 papers followed by Israel with 982 papers and United Kingdom with 656 papers. In terms of the average citation, papers published by researchers in Israel and United Kingdom have maintained the highest citations. Fig. 2 shows the results of the collaborations among various countries. 


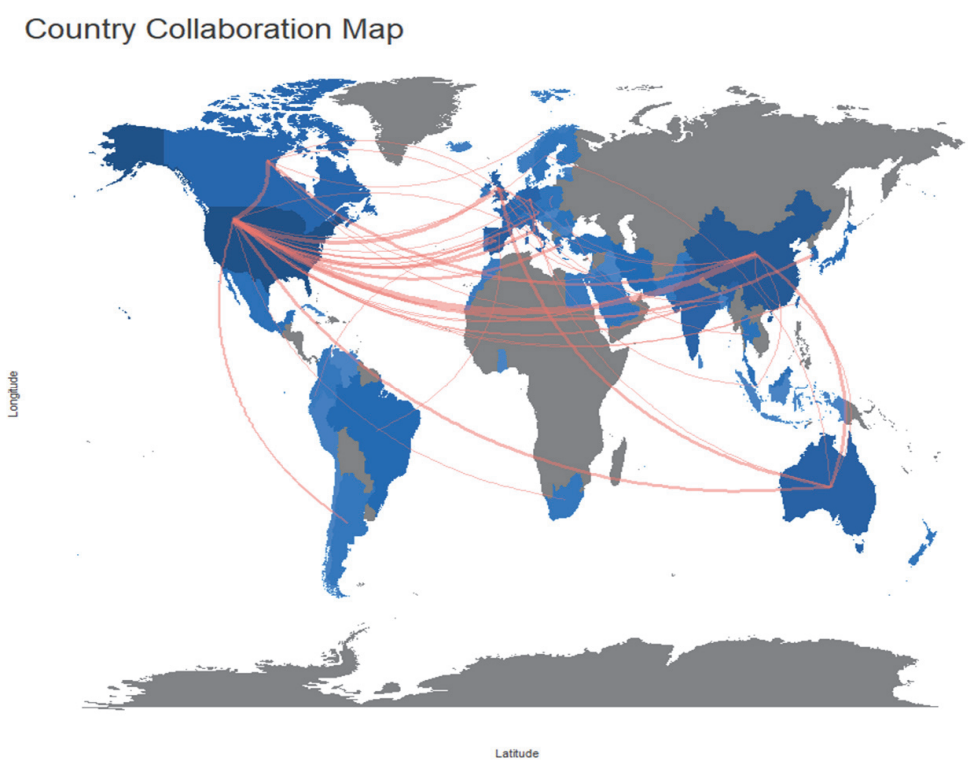

Fig. 2. Country collaboration map

As we can observe from the results of Fig. 2, there were strong collaboration between China and United States. Moreover, there was also a remarkable collaboration between the researchers in United States from one side and other countries.

\section{Highly cited papers}

Table 3 shows the summary of the most cited articles. As we can observe from the results of Table 3, the study by Goldenberg et al. (1999) received the highest citations in this area. The study on oral marketing and WOM advertising has been devoted on role of social networks in advertising. The focus of this study was on the power of WOM on e-business. In this study, they emphasized on the crucial role of personal communication among intimate groups as well as the impact of the lack of this close relationship among different groups. In fact, special attention was paid to two categories of "weak \& strong ties", and a survey was conducted on this subject. In the article by Trusov et al. (2009), the authors investigated the effects of the WOM advertising on the growth of members of social networks and compared the effects with traditional marketing. The results showed that people who had been absorbed into the market through WOM had significantly improved their survival in that position. Also, the method of calculating the cost of WOM advertising and its difference with other methods of advertising in this research was investigated. In another study, Costa et al. (2008) investigated on how to identify different kinds of tip spam on a popular Brazilian Location Based Social Networks system, namely Apontador. They determined three kinds of irregular tips, namely local marketing, pollution and, bad-mouthing and leveraged our characterization on a classification method which helps differentiate these tips with better accuracy. Trusov et al. (2010) developed a method to determine which users had substantial impacts on the activities of other people using the longitudinal records of members' log-in activities. The method identified the specific users most influence others' activity and did substantially better than simpler alternatives. They also found that, on average, approximately one-fifth of some user's friends actually impact their activity levels on the site.

Social media plays an important role in the area of health care and these days, people present the results of their blood test, X-ray, etc. to specialists through these facilities (Child et al., 2014). According to Greene et al. (2011), several disease-specific information are presently exchanged on Facebook and other online social networking sites. These are considered as new sources of knowledge, support, and engagement for patients living with different deceases such as chronic disease, yet the quality but the content of 
the information provided in these social networks are still poorly understood. Hemminki et al. (2010) studied the role of the cooperation between patient firms and the drug industry in Finland through social network. According to Jones et al. (2012), better use of e-health services by patients definitely provides better outcomes and reduces medical expenses. Mackey and Liang (2013) investigated the role of the Pharmaceutical digital marketing and governance and studied the role of illicit actors and challenges to global patient safety and public health. Despite the fact that social media may provide good information for users in health related topics. Weitzman et al. (2011) in a survey concluded that the information must be used cautiously. Nevertheless, many studies have suggested that employing people for advertising health related products may increase the profitability in drug industry. According to Fenner et al. (2012), recruitment the young people for health research by old techniques is now more costly and the use of social media and Internet may present an opportunity for innovative recruitment modalities. Arcia (2014) described that many people use Facebook advertisements as an inexpensive participant recruitment among women in early pregnancy. Some people call social media advertisement as tool with minimal regret (Aslay et al., 2015). Atkinson et al. (2017) performed a comprehensive study to see the effects of alcohol advertising on social networking sites. Privacy is another issue in social media communication. Syred et al. (2014) performed a survey on whether users should share their health related problems on social pages such as Facebook. They discussed that health promotion interventions on social networking sites could communicate individually tailored content to a large audience and also examined which elements of moderator and participant behavior stimulated and maintained interaction with some deceases on Facebook. Social media are also used to medical survey and it helps collecting useful information quickly (Nelson et al., 2014).

Tourism is another interesting areas which could be boosted using social media advertisement. These days, many travel agencies use social media to attract people all over the world (Vigil, 2010; Chen \& Law, 2016). Hernández-Méndez and Muñoz-Leiva (2015) performed a survey to find out what type of online advertising would be most effective for e-tourism in future. Social media is also used for political campaigns (Cunha et al., 2014; Boerman \& Kruikemeier, 2016). For instance, Boerman and Kruikemeier (2016).discussed how different political groups used Twitter for promoting their team leaders in presidential complains. Towner and Dulio (2012) discussed how political campaigns used social media to promote the presidential election in United States. Vesnic-Alujevic and Van Bauwel (2014) described how different European political groups used YouTube in the campaign for the European Parliament elections. Social learning is one of the interesting topics that has been mentioned in the context of social networking and advertising. It is important to categorize different types of consumers to get insights for social learning purposes both theoretically and managerially important. A consumer decides whether to adopt a product after receiving a private signal about product quality and observes the actions of others (Chen et al., 2011; Lazarsfeld \& Merton, 1954). People often make decisions after observing and learning from others' actions (Banerjee, 1992; Bikhchandani et al., 1992). Consider a consumer is deciding whether or not to buy a new electronic device. He/she has some preferences for a product but is unsure about its quality. She then notices that a friend has bought it, but others did not. Conventional wisdom suggests that the consumer is more likely to emulate his/her friends. As a result, people normally follow their friends in decisions such as which movie to watch and which political candidates to vote for (Moretti, 2011; Sinha \& Swearingen, 2001). Social media are important determinants of how people reach other people's opinion and form beliefs. In the past, most people used to get their feedback from other people in meeting, phone conversation, etc. Obviously, these kinds of feedback are limited to geographical locations, ethics group, etc. However, when a person shares his/her opinion through social media, anyone in the globe can reach and add comment. These days, well reputed online shoppers provide some forums to get customers' feedback about their products and services (Chen et al., 2011). For instance, Facebook and Amazon have built a common platform to share customers' feedback since 2010 and this has boosted the products (Villiard \& Moreno, 2012). Such instances present profound trends of consumer social learning based on electronic commerce and social life: (1) the consumers' ability to read the actions of others before making their own final decisions, and (2) the company's unprecedented potential to strategically implement various social networks among consumers. Compared with the situation 
where a consumer can only find others' behaviors within a physical location, people may now perform on a much larger scale on the Internet. By enhancing different methods such as social login with Facebook and other social network services, companies increasingly attempt to decide whether people can observe the behavior of other people (Zhang et al., 2015). Table 3 shows the summary of the most cited articles.

Table 3

The summary of the most cited articles

\begin{tabular}{|c|c|c|}
\hline Paper & Total & $\begin{array}{c}\text { TC per } \\
\text { Year }\end{array}$ \\
\hline GOLDENBERG J, 2001, MARK LETT & 967 & 53.7222 \\
\hline TRUSOV M, 2009, J MARK & 878 & 87.8 \\
\hline COSTA P, 2008, IEEE J SEL AREAS COMMUN & 361 & 32.8182 \\
\hline GREENE JA, 2011, J GEN INTERN MED & 347 & 43.375 \\
\hline NEKOVEE M, 2007, PHYS A STAT MECH APPL & 331 & 27.5833 \\
\hline TRUSOV M, 2010, J MARK RES & 318 & 35.3333 \\
\hline STIEGLITZ S, 2013, J MANAGE INF SYST & 293 & 48.8333 \\
\hline XIN RS, 2013, INT WORKSHOP GRAPH DATA MANAGE EXP SYST, GRADES - CO-LOCATED SIGMOD/PODS & 257 & 42.8333 \\
\hline RAMO DE, 2012, J MED INTERNET RES & 188 & 26.8571 \\
\hline FENNER Y, 2012, J MED INTERNET RES & 186 & 26.5714 \\
\hline GUHA S, 2008, PROC WORKSHOP ONLINE SOC NETW, WOSP & 169 & 15.3636 \\
\hline LIU K, 2010, IEEE TRANS SIGNAL PROCESS & 163 & 18.1111 \\
\hline TUCKER CE, 2014, J MARK RES & 143 & 28.6 \\
\hline ENDERS A, 2008, EUR MANAGE J & 133 & 12.0909 \\
\hline SHAH D, 2009, FOUND TRENDS NETWORKING & 126 & 11.4545 \\
\hline SEIFERT B, 2003, J BUS ETHICS & 118 & 7.375 \\
\hline MANCHANDA P, 2008, MARK SCI & 117 & 10.6364 \\
\hline TERLUTTER R, 2013, J ADVERT & 113 & 18.8333 \\
\hline CHANG RM, 2014, DECIS SUPPORT SYST & 112 & 22.4 \\
\hline WINER RS, 2009, J INTERACT MARK & 105 & 10.5 \\
\hline BAKSHY E, 2012, PROC ACM CONF ELECTRON COMMER & 100 & 14.2857 \\
\hline HUANG CY, 2010, TOUR MANAGE & 100 & 11.1111 \\
\hline BRENNAN L, 2010, J BUS RES & 99 & 11 \\
\hline DELIENS T, 2014, BMC PUBLIC HEALTH & 88 & 17.6 \\
\hline BENNETT WL, 2006, ANN AM ACAD POLIT SOC SCI & 81 & 6.2308 \\
\hline BROMLEY DB, 2000, CORP REPUTATION REV & 77 & 4.0526 \\
\hline LIANG BA, 2011, J AM MED ASSOC & 74 & 9.25 \\
\hline PROVOST F, 2009, PROC ACM SIGKDD INT CONF KNOWL DISCOV DATA MIN & 74 & 7.4 \\
\hline KAYTOUE M, 2012, WWW - PROC ANNU CONF WORLD WIDE WEB COMPANION & 70 & 10 \\
\hline LIANG BA, 2011, J MED INTERNET RES & 69 & 8.625 \\
\hline VAN HOYE G, 2009, J OCCUP ORGAN PSYCHOL & 69 & 6.9 \\
\hline GJOKA M, 2008, PROC WORKSHOP ONLINE SOC NETW, WOSP & 68 & 6.1818 \\
\hline FREEMAN B, 2008, J EPIDEMIOL COMMUNITY HEALTH & 66 & 6 \\
\hline KOSINSKI M, 2014, MACH LEARN & 65 & 13 \\
\hline CLEMONS EK, 2009, DECIS SUPPORT SYST & 65 & 6.5 \\
\hline RAMO DE, 2014, INTERNET INTERV & 63 & 12.6 \\
\hline SHRIVER SK, 2013, MANAGE SCI & 63 & 10.5 \\
\hline KAPP JM, 2013, J CANCER EDUC & 63 & 10.5 \\
\hline GUHA S, 2010, PROC ACM SIGCOMM INTERNET MEAS CONF IMC & 63 & 7 \\
\hline YANG WS, 2006, PROC ANNU HAWAII INT CONF SYST SCI & 63 & 4.8462 \\
\hline HE W, 2011, PROC INT CONF DISTRIB COMPUT SYST & 59 & 7.375 \\
\hline PHAN M, 2011, J GLOB FASH MARK & 58 & 7.25 \\
\hline SMITH AMA, 2004, SEX TRANSM INFECT & 57 & 3.8 \\
\hline YUAN NJ, 2013, COSN - PROC CONF ONLINE SOC NETWORKS & 55 & 9.1667 \\
\hline MÅNSSON M, 2011, ANN TOUR RES & 55 & 6.875 \\
\hline WEITZMAN ER, 2011, J AM MED INFORMATICS ASSOC & 55 & 6.875 \\
\hline NAM S, 2010, MARK SCI & 55 & 6.1111 \\
\hline HEIDEMANN J, 2010, PROC INTER CONF INF SYS & 54 & 6 \\
\hline SCOTT G, 2008, INT J DRUG POLICY & 53 & 4.8182 \\
\hline GRBOVIC M, 2015, PROC ACM SIGKDD INT CONF KNOWL DISCOV DATA MIN & 51 & 12.75 \\
\hline PARVEEN F, 2014, TELEMATICS INF & 50 & 10 \\
\hline YANG T, 2012, J COMPUT INF SYST & 49 & 7 \\
\hline ZHANG M, 2011, ELECTRON MARK & 48 & 6 \\
\hline KRASNOVA H, 2009, ICIS 2009 PROC - THIRTIETH INT CONF INF SYS & 47 & 4.7 \\
\hline ALKEMADE F, 2005, COMPUT ECON & 47 & 3.3571 \\
\hline BATTERHAM PJ, 2014, INT J METHODS PSYCHIATR RES & 46 & 9.2 \\
\hline LI Y, 2015, PROC VLDB ENDOW & 43 & 10.75 \\
\hline ZHANG C, 2012, ACM INT CONF PROC SER & 43 & 6.1429 \\
\hline
\end{tabular}


TOWNER TL, 2012, J POLIT MARK

LI YM, 2011, INF SCI

BHATT R, 2010, INT CONF INF KNOWLEDGE MANAGE

POLONEC LD, 2006, HEALTH COMMUN

CHU JL, 2013, J ADOLESC HEALTH

VIGIL JM, 2010, GROUP PROCESSES INTERGROUP RELAT

KNOLL J, 2016, INT J ADVERT

OSBORNE SL, 2015, VACCINE

DINH TN, 2014, IEEE ACM TRANS NETWORKING

CORAZZA O, 2014, J PSYCHOACT DRUGS

MART S, 2009, J GLOBAL DRUG POLICY PRACT

VOLKOVA S, 2015, PROC NATL CONF ARTIF INTELL

KOROLOVA A, 2010, PROC IEEE INT CONF DATA MIN ICDM

AMON KL, 2014, ACAD PEDIATR

JENSSEN BP, 2009, PEDIATRICS

ZHU WY, 2015, PROC ACM SIGKDD INT CONF KNOWL DISCOV DATA MIN

CLOSE S, 2013, J MED INTERNET RES

DELIENS T, 2015, BMC PUBLIC HEALTH

HALE TM, 2014, J MED INTERNET RES

ARMENATZOGLOU N, 2013, PROC VLDB ENDOW

BARRETO AM, 2013, J RES INTERACT MARK

ALOWIBDI JS, 2013, PROC IEEE/ACM INT CONF ADV SOC NETWORKS ANAL MIN, ASONAM

ZHANG X, 2012, INT J ENG EDUC

CLEMONS EK, 2007, ACM INT CONF PROC SER

HARRIS ML, 2015, AM J EPIDEMIOL

LIU K, 2010, ICASSP IEEE INT CONF ACOUST SPEECH SIGNAL PROCESS PROC

LEE J, 2016, INT J INF MANAGE

QIN J, 2014, PROC IEEE INFOCOM

TRUONG Y, 2010, J STRATEG MARK

DE CRISTOFARO E, 2014, PROC ACM SIGCOMM INTERNET MEAS CONF IMC

MALANDRINO D, 2013, PROC ACM CONF COMPUTER COMMUN SECUR

KIM D, 2013, ELECT COMMER RES APPL

LI YM, 2012, INT J ELECT COMMER

BISGIN H, 2012, WORLD WIDE WEB

MURILLO AC, 2012, IEEE COMPUT SOC CONF COMPUT VIS PATTERN RECOGN WORKSHOPS

DONELLE L, 2012, ONLINE J ISSUES NURS

ROMERO NL, 2011, BOTTOM LINE

PFEIFFER M, 2010, J ADVERT RES

CHO J, 2008, COMMUN RES

HADIJA Z, 2012, QUAL MARK RES

ENSOR J, 2001, J INF SCI

SOARES AM, 2012, J TRANSNATL MANAGE

MART SM, 2011, SUBST USE MISUSE

GUILLORY A, 2010, ICML - PROC, INT CONF MACH LEARN

JING P, 2018, IEEE TRANS KNOWL DATA ENG

YANG WS, 2008, EXPERT SYS APPL

WANG C, 2011, SIGIR - PROC INT ACM SIGIR CONF RES DEV INF RETR

NELSON EJ, 2014, J MED INTERNET RES

HASTINGS G, 2013, BMJ (ONLINE)

HASTINGS G, 2010, BMJ (ONLINE)

KWON KH, 2014, AM BEHAV SCI

GOEL S, 2014, MARK SCI

WEN C, 2009, ICIS 2009 PROC - THIRTIETH INT CONF INF SYS

GINSBURG M, 2002, PROC ANNU HAWAII INT CONF SYST SCI

As we can observe from the results of Fig. 3, "Marketing" is a one of the main issues in the discussion of social networks and advertising. Predicting the individuals' behaviors is the primary objective of the social sciences from the economists' perspective (Hiebert, 1974; Manski, 2007) to psychologies (Ajzen \& Fishbein, 1980), sociologist (Burt, 1987; Coleman et al., 1966), and business partners (Bass, 1969; Mahajan et al., 1990). The targeting decision is informed by predicting which individuals are most likely to take action, for example, to adopt an innovative product, to support a cause, to switch providers, or to change in response to marketing communications. Traditionally, as long as there are only a limited number of television stations and papers that the majority of people may reach, big corporations may easily reach both intended and unintended groups without wasting their times (Iyer et al., 2005). 


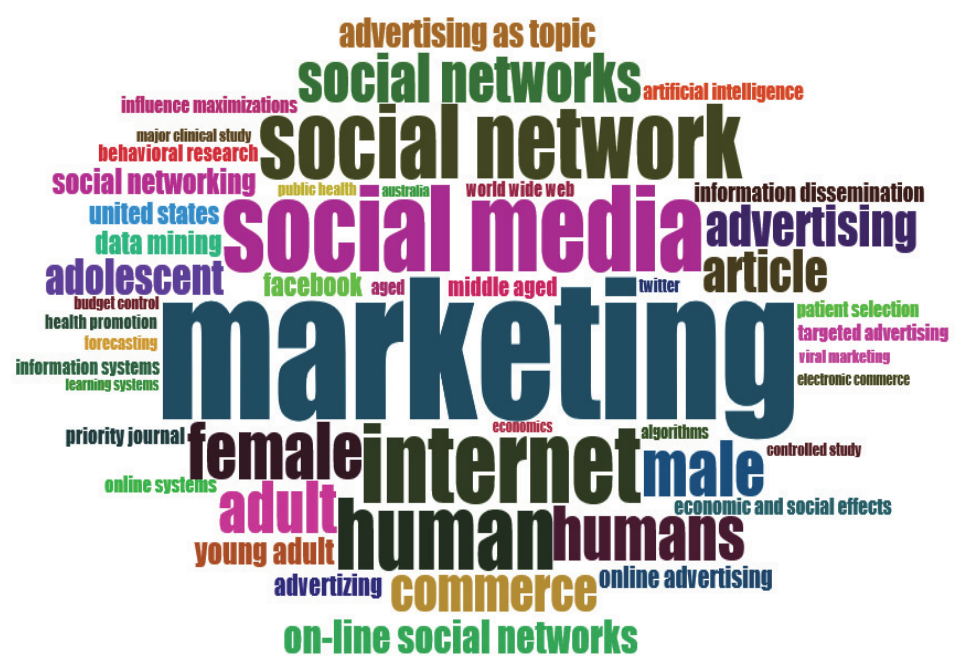

Fig. 3. The frequency of the keywords used in different advertising in social network studies

The rapid growth on media such as television, satellite, and Internet bandwidth have created more opportunities for small and medium enterprises to reach customers more easily. As a result, we see a more competition for marketing products and services. During the past few years, targeting has included whatever predictors were effective, affordable, and available. For more than a decade, online marketers have forecasted behavior at the individual level based on different variables such as age, gender, etc. (Goel \& Goldstein, 2014). Today, ad servers can respond to the text of the page being viewed, be it a news story or personal email, and deliver ads on the fly that match page content (contextual targeting) (Gupta et al., 2004; Malthouse \& Blattberg, 2005). After many years of advances, the baseline models for forecasting consumer behavior have reached a higher level. Moreover, new sources of data will constantly request the question of the degree to which targeting can be improved (Goel \& Goldstein, 2014).

\section{Contribution of the countries}

One of the interesting areas of the interest is to learn more about the contribution of different countries on the impacts of social networks on advertising. As we can observe from the results of Fig. 4, researchers from United States (610 papers), China (228 papers), Australia (144 papers) and spain (125) have contributed the most on advertising.

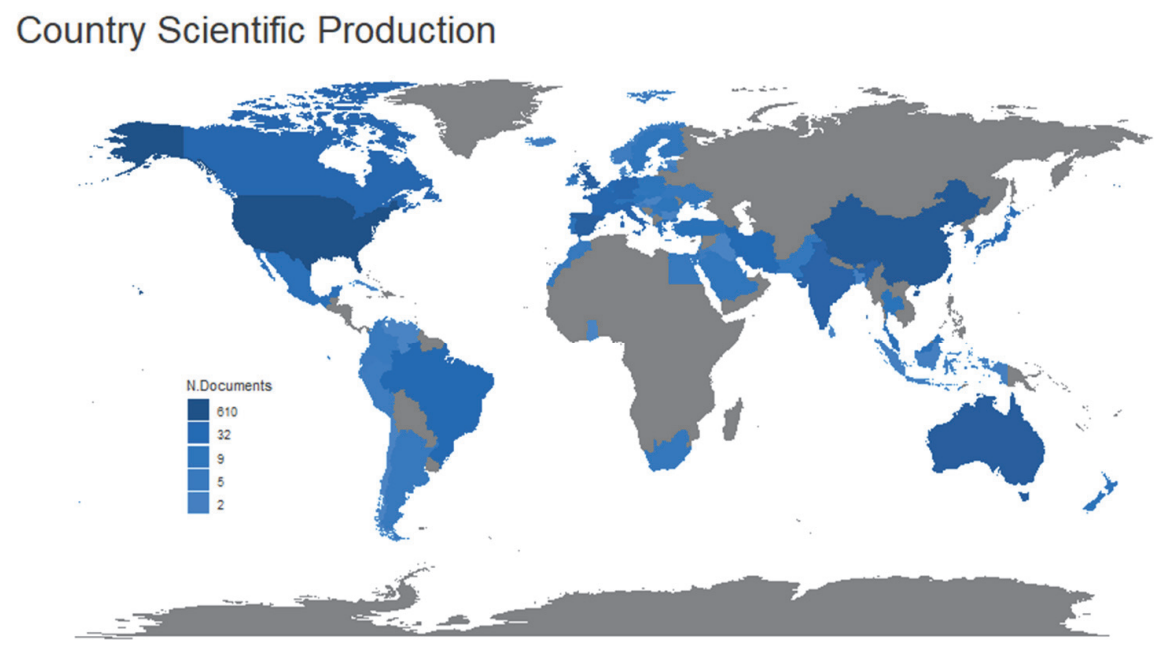

Fig. 4. The frequency of the keywords used in different advertising studies 


\section{Conclusion}

This study has tried to provide a comprehensive scientometrics review of the studies published in the literature associated with the impacts of social networks on advertisement. Social media has appeared to become an appropriate tool for promoting different products and services. Social media has been extensively used in the health care to provide medical treatment, it is also used to share news, pass on rumors or even promote political parties. We hope this survey provides sufficient information for interested researchers for future works.

\section{References}

Aggarwal, C. C., Kong, X., Gu, Q., Han, J., \& Philip, S. Y. (2014). Active learning: A survey. In Data Classification (pp. 589-623). Chapman and Hall/CRC.

Ajzen, I. (1987). Attitudes, traits, and actions: Dispositional prediction of behavior in personality and social psychology. In Advances in experimental social psychology (Vol. 20, pp. 1-63). Academic Press.

Alowibdi, J. S., Buy, U. A., Philip, S. Y., \& Stenneth, L. (2014, August). Detecting deception in online social networks. In Advances in Social Networks Analysis and Mining (ASONAM), 2014 IEEE/ACM International Conference on (pp. 383-390). IEEE.

Alkemade, F., La Poutré, H., \& Amman, H. M. (2006). Robust evolutionary algorithm design for socioeconomic simulation. Computational Economics, 28(4), 355-370.

Amon, K. L., Campbell, A. J., Hawke, C., \& Steinbeck, K. (2014). Facebook as a recruitment tool for adolescent health research: a systematic review. Academic Pediatrics, 14(5), 439-447.

Araujo, T., Neijens, P., \& Vliegenthart, R. (2015). What Motivates Consumers To Re-Tweet Brand Content?: The impact of information, emotion, and traceability on pass-along behavior. Journal of Advertising Research, 55(3), 284-295.

Armenatzoglou, N., Papadopoulos, S., \& Papadias, D. (2013). A general framework for geo-social query processing. Proceedings of the VLDB Endowment, 6(10), 913-924.

Arcia, A. (2014). Facebook advertisements for inexpensive participant recruitment among women in early pregnancy. Health Education \& Behavior, 41(3), 237-241.

Aslay, C., Lu, W., Bonchi, F., Goyal, A., \& Lakshmanan, L. V. (2015). Viral marketing meets social advertising: Ad allocation with minimum regret. Proceedings of the VLDB Endowment, 8(7), 814-825.

Atkinson, A. M., Ross-Houle, K. M., Begley, E., \& Sumnall, H. (2017). An exploration of alcohol advertising on social networking sites: an analysis of content, interactions and young people's perspectives. Addiction Research \& Theory, 25(2), 91-102.

Bakshy, E., Eckles, D., Yan, R., \& Rosenn, I. (2012, June). Social influence in social advertising: evidence from field experiments. In Proceedings of the 13th ACM conference on electronic commerce (pp. 146161). ACM.

Banerjee, A. V. (1992). A simple model of herd behavior. The quarterly journal of economics, 107(3), 797817.

Bass, F. M. (1969). A new product growth for model consumer durables. Management science, 15(5), 215227.

Batterham, P. J. (2014). Recruitment of mental health survey participants using Internet advertising: content, characteristics and cost effectiveness. International journal of methods in psychiatric research, 23(2), 184-191.

Belmonte-Jimenez, A. M. (1988). Young People as Users of Branded Applications on Mobile Devices.

Bennett, W. L., \& Manheim, J. B. (2006). The one-step flow of communication. The ANNALS of the American Academy of Political and Social Science, 608(1), 213-232.

Bhatt, R., Chaoji, V., \& Parekh, R. (2010, October). Predicting product adoption in large-scale social networks. In Proceedings of the 19th ACM international conference on Information and knowledge management (pp. 1039-1048). ACM

Bikhchandani, S., Hirshleifer, D., \& Welch, I. (1992). A theory of fads, fashion, custom, and cultural change as informational cascades. Journal of political Economy, 100(5), 992-1026. 
Bimpikis, K., Ozdaglar, A., \& Yildiz, E. (2016). Competitive targeted advertising over networks. Operations Research, 64(3), 705-720.

Bisgin, H., Agarwal, N., \& Xu, X. (2012). A study of homophily on social media. World Wide Web, 15(2), 213-232.

Boerman, S. C., \& Kruikemeier, S. (2016). Consumer responses to promoted tweets sent by brands and political parties. Computers in Human Behavior, 65, 285-294.

Brennan, L., \& Binney, W. (2010). Fear, guilt, and shame appeals in social marketing. Journal of business Research, 63(2), 140-146.

Bromley, D. (2002). Comparing corporate reputations: League tables, quotients, benchmarks, or case studies?. Corporate reputation review, 5(1), 35-50.

Burt, R. S. (1987). Social contagion and innovation: Cohesion versus structural equivalence. American journal of Sociology, 92(6), 1287-1335.

Chen, Y. F., \& Law, R. (2016). A review of research on electronic word-of-mouth in hospitality and tourism management. International Journal of Hospitality \& Tourism Administration, 17(4), 347-372.

Chen, Y., Wang, Q., \& Xie, J. (2011). Online social interactions: A natural experiment on word of mouth versus observational learning. Journal of marketing research, 48(2), 238-254.

Child, R. J. H., Mentes, J. C., Pavlish, C., \& Phillips, L. R. (2014). Using Facebook and participant information clips to recruit emergency nurses for research. Nurse Researcher (2014+), 21(6), 16.

Cho, J. (2008). Political ads and citizen communication. Communication Research, 35(4), 423-451.

Clemons, E. K. (2009). The complex problem of monetizing virtual electronic social networks. Decision Support Systems, 48(1), 46-56.

Clemons, E. K., Barnett, S., \& Appadurai, A. (2007, August). The future of advertising and the value of social network websites: some preliminary examinations. In Proceedings of the ninth international conference on Electronic commerce (pp. 267-276). ACM.

Close, S., Smaldone, A., Fennoy, I., Reame, N., \& Grey, M. (2013). Using information technology and social networking for recruitment of research participants: experience from an exploratory study of pediatric Klinefelter syndrome. Journal of medical Internet research, 15(3).

Corazza, O., Valeriani, G., Bersani, F. S., Corkery, J., Martinotti, G., Bersani, G., \& Schifano, F. (2014). "Spice,"“kryptonite,"“black mamba": An overview of brand names and marketing strategies of novel psychoactive substances on the web. Journal of Psychoactive Drugs, 46(4), 287-294.

Costa, H., Benevenuto, F., \& Merschmann, L. H. (2013, March). Detecting tip spam in location-based social networks. In Proceedings of the 28th Annual ACM Symposium on Applied Computing (pp. 724729). ACM.

Costa, H., Merschmann, L. H., Barth, F., \& Benevenuto, F. (2014). Pollution, bad-mouthing, and local marketing: The underground of location-based social networks. Information Sciences, 279, 123-137.

Cunha, E., Magno, G., Gonçalves, M. A., Cambraia, C., \& Almeida, V. (2014). He votes or she votes? Female and male discursive strategies in Twitter political hashtags. PloS one, 9(1), e87041.

De Cristofaro, E., Friedman, A., Jourjon, G., Kaafar, M. A., \& Shafiq, M. Z. (2014, November). Paying for likes?: Understanding facebook like fraud using honeypots. In Proceedings of the 2014 Conference on Internet Measurement Conference (pp. 129-136). ACM.

Deliens, T., Clarys, P., De Bourdeaudhuij, I., \& Deforche, B. (2014). Determinants of eating behaviour in university students: a qualitative study using focus group discussions. BMC public health, 14(1), 53

Deliens, T., Deforche, B., De Bourdeaudhuij, I., \& Clarys, P. (2015). Determinants of physical activity and sedentary behaviour in university students: a qualitative study using focus group discussions. $B M C$ Public Health, 15(1), 201.

Dinh, T. N., Zhang, H., Nguyen, D. T., \& Thai, M. T. (2014). Cost-effective viral marketing for timecritical campaigns in large-scale social networks. IEEE/ACM Transactions on Networking (ToN), 22(6), 2001-2011.

Donelle, L., \& Booth, R. G. (2012). Health tweets: an exploration of health promotion on twitter. Online Journal of nursing, 17(4).

Enders, A., Hungenberg, H., Denker, H. P., \& Mauch, S. (2008). The long tail of social networking.: Revenue models of social networking sites. European Management Journal, 26(3), 199-211. 
Ensor, J., Cottam, A., \& Band, C. (2001). Fostering knowledge management through the creative work environment: a portable model from the advertising industry. Journal of Information Science, 27(3), 147-155.

Fenner, Y., Garland, S. M., Moore, E. E., Jayasinghe, Y., Fletcher, A., Tabrizi, S. N., ... \& Wark, J. D. (2012). Web-based recruiting for health research using a social networking site: an exploratory study. Journal of medical Internet research, 14(1).

Freeman, B., \& Chapman, S. (2008). Gone viral? Heard the buzz? A guide for public health practitioners and researchers on how Web 2.0 can subvert advertising restrictions and spread health information. Journal of Epidemiology \& Community Health, 62(9), 778-782.

Ginsburg, M., \& Weisband, S. (2002, January). Social capital and volunteerism in virtual communities: The case of the internet chess club. In hicss (p. 171b). IEEE.

Gjoka, M., Sirivianos, M., Markopoulou, A., \& Yang, X. (2008, August). Poking facebook: characterization of osn applications. In Proceedings of the first workshop on Online social networks (pp. 31-36). ACM.

Goel, S., \& Goldstein, D. G. (2014). Predicting individual behavior with social networks. Marketing Science, 33(1), 82-93.

Goldenberg, J., Libai, B., \& Muller, E. (2001). Talk of the network: A complex systems look at the underly process of word-of-mouth. Marketing letters, 12(3), 211-223.

Grbovic, M., Radosavljevic, V., Djuric, N., Bhamidipati, N., Savla, J., Bhagwan, V., \& Sharp, D. (2015, August). E-commerce in your inbox: Product recommendations at scale. In Proceedings of the 21th ACM SIGKDD International Conference on Knowledge Discovery and Data Mining (pp. 1809-1818). ACM.

Greene, J. A., Choudhry, N. K., Kilabuk, E., \& Shrank, W. H. (2011). Online social networking by patients with diabetes: a qualitative evaluation of communication with Facebook. Journal of general internal medicine, 26(3), 287-292.

Gupta, S., Lehmann, D. R., \& Stuart, J. A. (2004). Valuing customers. Journal of marketing research, 41(1), 7-18.

Guha, S., Cheng, B., \& Francis, P. (2010, November). Challenges in measuring online advertising systems. In Proceedings of the 10th ACM SIGCOMM conference on Internet measurement (pp. 81-87). ACM.

Guillory, A., \& Bilmes, J. (2010). Interactive submodular set cover. arXiv preprint arXiv:1002.3345.

Guha, S., Tang, K., \& Francis, P. (2008, August). NOYB: Privacy in online social networks. In Proceedings of the first workshop on Online social networks (pp. 49-54). ACM.

Gunasekaran, B., Jayasinghe, Y., Fenner, Y., Moore, E. E., Wark, J. D., Fletcher, A., ... \& Garland, S. M. (2013). Knowledge of human papillomavirus and cervical cancer among young women recruited using a social networking site. Sex Transm Infect, 89(4), 327-329.

Hadija, Z., Barnes, S. B., \& Hair, N. (2012). Why we ignore social networking advertising. Qualitative Market Research: An International Journal, 15(1), 19-32.

Hale, T. M., Pathipati, A. S., Zan, S., \& Jethwani, K. (2014). Representation of health conditions on Facebook: content analysis and evaluation of user engagement. Journal of medical Internet research, 16(8).

Hansen, S. S., \& Lee, J. K. (2013). What drives consumers to pass along marketer-generated eWOM in social network games? social and game factors in play. Journal of theoretical and applied electronic commerce research, 8(1), 53-68.

Hastings, G., \& Sheron, N. (2013). Alcohol marketing: grooming the next generation.

Hastings, G., Brooks, O., Stead, M., Angus, K., Anker, T., \& Farrell, T. (2010). Alcohol advertising: the last chance saloon. $B M J, 340$ (23 Jan), 184-186.

Harris, M. L., Loxton, D., Wigginton, B., \& Lucke, J. C. (2015). Harris et al. respond to "Social media recruitment". American journal of epidemiology, 181(10), 750-751.

Heidemann, J., Klier, M., \& Probst, F. (2012). Online social networks: A survey of a global phenomenon. Computer networks, 56(18), 3866-3878. 
Hemminki, E., Toiviainen, H. K., \& Vuorenkoski, L. (2010). Co-operation between patient organisations and the drug industry in Finland. Social science \& medicine, 70(8), 1171-1175.

Hernández-Méndez, J., \& Muñoz-Leiva, F. (2015). What type of online advertising is most effective for eTourism 2.0? An eye tracking study based on the characteristics of tourists. Computers in Human Behavior, 50, 618-625.

Hiebert, L. D. (1974). Risk, learning, and the adoption of fertilizer responsive seed varieties. American Journal of Agricultural Economics, 56(4), 764-768.

Huang, C. Y., Chou, C. J., \& Lin, P. C. (2010). Involvement theory in constructing bloggers' intention to purchase travel products. Tourism Management, 31(4), 513-526.

Iyer, G., Soberman, D., \& Villas-Boas, J. M. (2005). The targeting of advertising. Marketing Science, 24(3), 461-476.

Jenssen, B. P., Klein, J. D., Salazar, L. F., Daluga, N. A., \& DiClemente, R. J. (2009). Exposure to Tobacco on the Internet: Content Analysis of Adolescents9 Internet Use. Pediatrics, 124(2), e180-e186.

Jing, P., Su, Y., Nie, L., Bai, X., Liu, J., \& Wang, M. (2018). Low-rank multi-view embedding learning for micro-video popularity prediction. IEEE Transactions on Knowledge and Data Engineering, 30(8), 1519-1532

Jones, R. B., O'Connor, A., Brelsford, J., Parsons, N., \& Skirton, H. (2012). Costs and difficulties of recruiting patients to provide e-health support: pilot study in one primary care trust. BMC medical informatics and decision making, 12(1), 25.

Kaytoue, M., Silva, A., Cerf, L., Meira Jr, W., \& Raïssi, C. (2012, April). Watch me playing, i am a professional: a first study on video game live streaming. In Proceedings of the 21st International Conference on World Wide Web (pp. 1181-1188). ACM.

Kapp, J. M., Peters, C., \& Oliver, D. P. (2013). Research recruitment using Facebook advertising: big potential, big challenges. Journal of Cancer Education, 28(1), 134-137.

Kim, D. (2013). Under what conditions will social commerce business models survive?. Electronic Commerce Research and Applications, 12(2), 69-77.

Kosinski, M., Bachrach, Y., Kohli, P., Stillwell, D., \& Graepel, T. (2014). Manifestations of user personality in website choice and behaviour on online social networks. Machine learning, 95(3), 357-380.

Krasnova, H., Hildebrand, T., \& Guenther, O. (2009). Investigating the value of privacy on online social networks: conjoint analysis.

Knoll, J. (2016). Advertising in social media: a review of empirical evidence. International Journal of Advertising, 35(2), 266-300.

Korolova, A. (2010, December). Privacy violations using microtargeted ads: A case study. In Data Mining Workshops (ICDMW), 2010 IEEE International Conference on (pp. 474-482). IEEE.

Kwon, K. H., Stefanone, M. A., \& Barnett, G. A. (2014). Social network influence on online behavioral choices: exploring group formation on social network sites. American Behavioral Scientist, 58(10), 1345-1360.

Lazarsfeld, P. F., \& Merton, R. K. (1954). Friendship as a social process: A substantive and methodological analysis. Freedom and control in modern society, 18(1), 18-66.

Lee, J., \& Hong, I. B. (2016). Predicting positive user responses to social media advertising: The roles of emotional appeal, informativeness, and creativity. International Journal of Information Management, 36(3), 360-373.

Liang, B. A., \& Mackey, T. (2011). Direct-to-consumer advertising with interactive internet media: global regulation and public health issues. Jama, 305(8), 824-825.

Li, Y., Zhang, D., \& Tan, K. L. (2015). Real-time targeted influence maximization for online advertisements. Proceedings of the VLDB Endowment, 8(10), 1070-1081.

Liu, K., \& Zhao, Q. (2010, March). Distributed learning in cognitive radio networks: Multi-armed bandit with distributed multiple players. In Acoustics Speech and Signal Processing (ICASSP), 2010 IEEE International Conference on (pp. 3010-3013). IEEE.

Li, Y. M., Lee, Y. L., \& Lien, N. J. (2012). Online social advertising via influential endorsers. International Journal of Electronic Commerce, 16(3), 119-154. 
Lloret Romero, N. (2011). ROI. Measuring the social media return on investment in a library. The Bottom Line, 24(2), 145-151.

Liu, K., \& Zhao, Q. (2010). Distributed learning in multi-armed bandit with multiple players. IEEE Transactions on Signal Processing, 58(11), 5667-5681.

Malthouse, E. C., \& Blattberg, R. C. (2005). Can we predict customer lifetime value?. Journal of interactive marketing, 19(1), 2-16.

Manchanda, P., Xie, Y., \& Youn, N. (2008). The role of targeted communication and contagion in product adoption. Marketing Science, 27(6), 961-976

Månsson, M. (2011). Mediatized tourism. Annals of Tourism Research, 38(4), 1634-1652.

Weitzman, E. R., Cole, E., Kaci, L., \& Mandl, K. D. (2011). Social but safe? Quality and safety of diabetes-related online social networks. Journal of the American Medical Informatics Association, 18(3), 292-297

Mart, S., Mergendoller, J., \& Simon, M. (2009). Alcohol promotion on Facebook. Journal of Global Drug Policy and Practice, 3(3), 1-8.

Margarida Barreto, A. (2013). Do users look at banner ads on Facebook?. Journal of Research in Interactive Marketing, 7(2), 119-139.

Mart, S. M. (2011). Alcohol marketing in the 21st century: new methods, old problems. Substance use \& misuse, 46(7), 889-892.

Mackey, T. K., \& Liang, B. A. (2013). Pharmaceutical digital marketing and governance: illicit actors and challenges to global patient safety and public health. Globalization and health, 9(1), 45.

Malandrino, D., Scarano, V., \& Spinelli, R. (2013, September). How increased awareness can impact attitudes and behaviors toward online privacy protection. In Social Computing (SocialCom), 2013 International Conference on (pp. 57-62). IEEE.

Manderson, L., Canaway, R., Unantenne, N., Oldenburg, B., Lin, V., Hollingsworth, B., \& de Courten, M. (2012). Care seeking, use of complementary therapies and self management among people with type 2 diabetes and cardiovascular disease. Australian Journal of Herbal Medicine, 24(1), 10.

Manski, C. F. (2009). Identification for prediction and decision. Harvard University Press.

.Moretti, E. (2011). Social learning and peer effects in consumption: Evidence from movie sales. Rev. Econom. Stud.78(1):356-393.

Mortazavi, M., Rahim Esfidani, M., \& Shaemi Barzoki, A. (2014). Influencing VSN users' purchase intentions: The roles of flow, trust and eWOM. Journal of Research in Interactive Marketing, 8(2), 102123.

Murillo, A. C., Kwak, I. S., Bourdev, L., Kriegman, D., \& Belongie, S. (2012, June). Urban tribes:

Nam, S., Manchanda, P., \& Chintagunta, P. K. (2010). The effect of signal quality and contiguous word of mouth on customer acquisition for a video-on-demand service. Marketing Science, 29(4), 690-700.

Nekovee, M., Moreno, Y., Bianconi, G., \& Marsili, M. (2007). Theory of rumour spreading in complex social networks. Physica A: Statistical Mechanics and its Applications, 374(1), 457-470.

Nelson, E. J., Hughes, J., Oakes, J. M., Pankow, J. S., \& Kulasingam, S. L. (2014). Estimation of geographic variation in human papillomavirus vaccine uptake in men and women: an online survey using facebook recruitment. Journal of Medical Internet Research, 16(9).

Osborne, S. L., Tabrizi, S. N., Brotherton, J. M., Cornall, A. M., Wark, J. D., Wrede, C. D., ... \& Vaccine Study Group. (2015). Assessing genital human papillomavirus genoprevalence in young Australian women following the introduction of a national vaccination program. Vaccine, 33(1), 201-208.

Parveen, F., Jaafar, N. I., \& Ainin, S. (2015). Social media usage and organizational performance: Reflections of Malaysian social media managers. Telematics and Informatics, 32(1), 67-78.

Pfeiffer, M., \& Zinnbauer, M. (2010). Can Old Media Enhance New Media?: How Traditional Advertising Pays off for an Online Social Network. Journal of Advertising Research, 50(1), 42-49.

Polonec, L. D., Major, A. M., \& Atwood, L. E. (2006). Evaluating the Believability and Effectiveness of the Social Norms Message" Most Students Drink 0 to 4 Drinks When They Party". Health communication, 20(1), 23-34. 
Provost, F., Dalessandro, B., Hook, R., Zhang, X., \& Murray, A. (2009, June). Audience selection for online brand advertising: privacy-friendly social network targeting. In Proceedings of the 15th ACM SIGKDD international conference on Knowledge discovery and data mining (pp. 707-716). ACM.

Qin, J., Zhu, H., Zhu, Y., Lu, L., Xue, G., \& Li, M. (2016). Post: Exploiting dynamic sociality for mobile advertising in vehicular networks. IEEE Transactions on Parallel and Distributed Systems, 27(6), 17701782.

Ramo, D. E., \& Prochaska, J. J. (2012). Broad reach and targeted recruitment using Facebook for an online survey of young adult substance use. Journal of medical Internet research, 14(1)

Ramo, D. E., Rodriguez, T. M., Chavez, K., Sommer, M. J., \& Prochaska, J. J. (2014). Facebook recruitment of young adult smokers for a cessation trial: methods, metrics, and lessons learned. Internet Interventions, 1(2), 58-64.

Remschmidt, C., Walter, D., Schmich, P., Wetzstein, M., Deleré, Y., \& Wichmann, O. (2014). Knowledge, attitude, and uptake related to human papillomavirus vaccination among young women in Germany recruited via a social media site. Human vaccines \& immunotherapeutics, 10(9), 2527-2535.

Scott, G. (2008). "They got their program, and I got mine": A cautionary tale concerning the ethical implications of using respondent-driven sampling to study injection drug users. International Journal of Drug Policy, 19(1), 42-51.

Seifert, B., Morris, S. A., \& Bartkus, B. R. (2003). Comparing big givers and small givers: Financial correlates of corporate philanthropy. Journal of business ethics, 45(3), 195-211.

Shah, D. (2009). Gossip algorithms. Foundations and Trends ${ }^{\circledR}$ in Networking, 3(1), 1-125.

Shriver, S. K., Nair, H. S., \& Hofstetter, R. (2013). Social ties and user-generated content: Evidence from an online social network. Management Science, 59(6), 1425-1443.

Sinha, R. R., \& Swearingen, K. (2001, June). Comparing recommendations made by online systems and friends. In DELOS workshop: personalisation and recommender systems in digital libraries (Vol. 106).

Smith, A. M. A., Grierson, J., Wain, D., Pitts, M., \& Pattison, P. (2004). Associations between the sexual behaviour of men who have sex with men and the structure and composition of their social networks. Sexually transmitted infections, 80(6), 455-458

Soares, A. M., Pinho, J. C., \& Nobre, H. (2012). From social to marketing interactions: The role of social networks. Journal of Transnational Management, 17(1), 45-62.

Stieglitz, S., \& Dang-Xuan, L. (2013). Emotions and information diffusion in social media-sentiment of microblogs and sharing behavior. Journal of Management Information Systems, 29(4), 217-248.

Sun, Y. F., \& Li, S. (2014). Similarity-based community detection in social network of microblog. Journal of Computer Research and Development, 51(12), 2797-2807.

Terlutter, R., \& Capella, M. L. (2013). The gamification of advertising: analysis and research directions of in-game advertising, advergames, and advertising in social network games. Journal of Advertising, 42(2-3), 95-112.

Syred, J., Naidoo, C., Woodhall, S. C., \& Baraitser, P. (2014). Would you tell everyone this? Facebook conversations as health promotion interventions. Journal of Medical Internet Research, 16(4).

Towner, T. L., \& Dulio, D. A. (2012). New media and political marketing in the United States: 2012 and beyond. Journal of Political Marketing, 11(1-2), 95-119.

Trusov, M., Bucklin, R. E., \& Pauwels, K. (2009). Effects of word-of-mouth versus traditional marketing: findings from an internet social networking site. Journal of marketing, 73(5), 90-102.

Trusov, M., Bodapati, A. V., \& Bucklin, R. E. (2010). Determining influential users in internet social networks. Journal of Marketing Research, 47(4), 643-658.

Truong, Y., \& Simmons, G. (2010). Perceived intrusiveness in digital advertising: strategic marketing implications. Journal of Strategic Marketing, 18(3), 239-256.

Tucker, C. E. (2014). Social networks, personalized advertising, and privacy controls. Journal of Marketing Research, 51(5), 546-562.

Van Hoye, G., Van Hooft, E. A., \& Lievens, F. (2009). Networking as a job search behaviour: A social network perspective. Journal of Occupational and Organizational Psychology, 82(3), 661-682. 
Vesnic-Alujevic, L., \& Van Bauwel, S. (2014). YouTube: A political advertising tool? A case study of the use of YouTube in the campaign for the European Parliament elections. Journal of Political Marketing, 13(3), 195-212.

Vigil, J. M. (2010). Political leanings vary with facial expression processing and psychosocial functioning. Group Processes \& Intergroup Relations, 13(5), 547-558.

Villiard, H., \& Moreno, M. A. (2012). Fitness on facebook: advertisements generated in response to profile content. Cyberpsychology, Behavior, and Social Networking, 15(10), 564-568.

Volkova, S., Bachrach, Y., Armstrong, M., \& Sharma, V. (2015, January). Inferring Latent User Properties from Texts Published in Social Media. In AAAI (pp. 4296-4297).

Wang, C., Raina, R., Fong, D., Zhou, D., Han, J., \& Badros, G. (2011, July). Learning relevance from heterogeneous social network and its application in online targeting. In Proceedings of the 34th international ACM SIGIR conference on Research and development in Information Retrieval (pp. 655-664). ACM.

Wei, C., Khoury, R., \& Fong, S. (2013). Web 2.0 Recommendation service by multi-collaborative filtering trust network algorithm. Information Systems Frontiers, 15(4), 533-551.

Wen, C., Tan, B. C., \& Chang, K. T. T. (2009). Advertising effectiveness on social network sites: an investigation of tie strength, endorser expertise and product type on consumer purchase intention. ICIS 2009 Proceedings, 151.

Winer, R. S. (2009). New communications approaches in marketing: Issues and research directions. Journal of interactive marketing, 23(2), 108-117.

Xin, R. S., Gonzalez, J. E., Franklin, M. J., \& Stoica, I. (2013, June). Graphx: A resilient distributed graph system on spark. In First International Workshop on Graph Data Management Experiences and Systems (p. 2). ACM.

Yang, W. S., Dia, J. B., Cheng, H. C., \& Lin, H. T. (2006, January). Mining social networks for targeted advertising. In System Sciences, 2006. HICSS'06. Proceedings of the 39th Annual Hawaii International Conference on (Vol. 6, pp. 137a-137a). IEEE.

Yang, W. S., \& Dia, J. B. (2008). Discovering cohesive subgroups from social networks for targeted advertising. Expert Systems with Applications, 34(3), 2029-2038.

Yang, T. (2012). The decision behavior of Facebook users. Journal of Computer Information Systems, $52(3), 50-59$.

Zhang, C., Shou, L., Chen, K., Chen, G., \& Bei, Y. (2012a). Evaluating geo-social influence in locationbased social networks. In Proceedings of the 21st ACM international conference on Information and knowledge management (pp. 1442-1451). ACM.

Zhang, X., de Pablos, P. O., \& Zhu, H. (2012b). The impact of second life on team learning outcomes from the perspective of IT capabilities. The International journal of engineering education, 28(6), $1388-1392$.

Zhang, M., Jansen, B. J., \& Chowdhury, A. (2011). Business engagement on Twitter: a path analysis. Electronic Markets, 21(3), 161.

Zhang, J., Liu, Y., \& Chen, Y. (2015). Social learning in networks of friends versus strangers. Marketing Science, 34(4), 573-589.

Zhang, H., Zhang, H., Kuhnle, A., \& Thai, M. T. (2016a). Profit maximization for multiple products in online social networks. In Computer Communications, IEEE INFOCOM 2016-The 35th Annual IEEE International Conference on (pp. 1-9). IEEE.

Zhang, Y., Bai, Y., Chen, L., Bian, K., \& Li, X. (2016b). Influence maximization in messenger-based social networks. In Global Communications Conference (GLOBECOM), 2016 IEEE (pp. 1-6). IEEE.

Zubcsek, P. P., \& Sarvary, M. (2011). Advertising to a social network. Quantitative Marketing and Economics, 9(1), 71-107.

Zhu, W. Y., Peng, W. C., Chen, L. J., Zheng, K., \& Zhou, X. (2015, August). Modeling user mobility for location promotion in location-based social networks. In Proceedings of the 21th ACM SIGKDD International Conference on Knowledge Discovery and Data Mining (pp. 1573-1582). ACM. 
(C) 2019 by the authors; licensee Growing Science, Canada. This is an open access article distributed under the terms and conditions of the Creative Commons Attribution (CC-BY) license (http://creativecommons.org/licenses/by/4.0/). 